\title{
PENGARUH AUDITOR SWITCHING, LIKUIDITAS, LEVERAGE, DISCLOSURE DAN FINANCIAL DISTRESS TERHADAP KEMUNGKINAN PENERIMAAN OPINI AUDIT GOING CONCERN
}

(Studi pada Perusahaan Pertambangan yang Terdaftar di Bursa Efek Indonesia

Tahun 2013 - 2016)

\author{
Indri Septiana \\ Universitas Multimedia Nusantara \\ indriseptiana96@gmail.com \\ Patricia Diana \\ Universitas Multimedia Nusantara \\ patricia@umn.ac.id
}

\begin{abstract}
The objective of this study was to obtain empirical evidence about the effect of auditor switching, liquidity, leverage, disclosure and financial distress on the probability of going concern audit opinion. The object of this study is the mining companies listed in Indonesia Stock Exchange in 2013 - 2016.

Samples of this research were chosen by using purposive sampling and got 8 mining companies that matched the criteria. The criteria used for choosing the samples are listed on BEI as mining company during period 2013-2016, publish the annual report and audited financial statement in Rupiah, and has a net loss for two periods in a row. This research use regression logistic because the dependent variable measured by nominal scale. The result of this research showed that auditor switching, liquidity, leverage, disclosure and financial distress didn't have effect to the probability of going concern audit opinion.
\end{abstract}

Keywords: Acceptance probability of going concern audit opinion, auditor switching, disclosure, financial distress, leverage, liquidity.

\section{PENDAHULUAN}

Menurut Undang-Undang Republik Indonesia No. 4 Tahun 2009 Tentang Pertambangan Mineral dan Batubara, usaha pertambangan adalah kegiatan dalam rangka pengusahaan mineral atau batubara yang meliputi tahapan kegiatan penyelidikan umum, eksplorasi, studi kelayakan, konstruksi, penambangan, pengolahan, dan pemurnian, pengangkutan dan penjualan, serta pasca tambang. Hasil tambang yang banyak ditemukan di Indonesia antara lain adalah batubara, minyak bumi, logam, mineral, serta berbagai batuan lainnya. Sektor pertambangan adalah salah satu sektor ekonomi yang penting di Indonesia. Hal ini ditunjukkan dengan besarnya kontribusi ekspor sektor pertambangan terhadap total ekspor 
Indonesia. Berdasarkan data Kementerian Perindustrian, sektor pertambangan menempati urutan kedua sebagai penyumbang ekspor terbesar selama tahun 2012 sampai dengan 2016 yang membuktikan bahwa sektor pertambangan merupakan salah satu sektor penting bagi perekonomian Indonesia. Tahun 2015 merupakan tahun yang buruk bagi perusahaan pertambangan di berbagai negara di seluruh dunia. Jack O’Callaghan, Global Mining Leader di PricewaterhouseCoopers (PwC), menyatakan bahwa 40 perusahaan pertambangan terbesar di dunia mencatat kerugian bersih kolektif sebesar US\$27 Miliar pada tahun 2015 (PwC, 2015). Hal ini terjadi karena penurunan harga komoditas sebesar $25 \%$ dibandingkan harga di tahun 2014. Pada tahun 2014, proporsi nilai investasi sektor pertambangan sebesar $11,5 \%$ dan terus menurun menjadi 9,9\% di tahun 2015 dan 7\% di tahun 2016. Turunnya investasi dapat berakibat pada berkurangnya modal untuk menunjang kegiatan operasional perusahaan dalam tujuannya menciptakan laba. Ketika perusahaan mengalami penurunan pendapatan yang tidak diikuti dengan efisiensi beban, maka laba yang dihasilkan akan semakin berkurang sehingga menimbulkan kerugian. Jika kerugian terus terjadi, maka perusahaan akan mengalami kesulitan untuk mempertahankan kelangsungan usahanya.

Going concern adalah kelangsungan hidup suatu badan usaha yang dijadikan asumsi dalam pelaporan keuangan entitas. Asumsi ini mengharuskan perusahaan secara operasional memiliki kemampuan mempertahankan hidupnya dan akan melanjutkan usahanya di masa depan. Informasi mengenai kemampuan perusahaan untuk mempertahankan kelangsungan usahanya dapat diberikan oleh seorang auditor independen dalam hasil laporan auditnya. Dalam Standar Audit 570 mengenai kelangsungan usaha paragraf ke enam, dijelaskan bahwa auditor bertanggung jawab untuk memperoleh bukti yang cukup dan tepat tentang ketepatan penggunaan asumsi kelangsungan usaha oleh manajemen dalam penyusunan dan penyajian laporan keuangan dan untuk menyimpulkan apakah 
terdapat suatu ketidakpastian material tentang kemampuan entitas untuk mempertahankan kelangsungan hidupnya (IAPI, 2013).

Auditor switching adalah pergantian auditor atau Kantor Akuntan Publik (KAP) yang dilakukan oleh perusahaan (Setiadamayanthi, 2016). Terdapat dua jenis pergantian auditor yaitu mandatory switching dan voluntary switching. Mandatory switching adalah pergantian auditor atau KAP yang didasarkan pada peraturan pemerintah. Sedangkan, voluntary auditor switching adalah pergantian auditor yang dilakukan secara sukarela sebelum jangka waktu yang telah diatur dalam peraturan. Voluntary auditor switching, menyebabkan hubungan kerja antara auditor dengan klien menjadi lebih singkat karena pergantian auditor terjadi sebelum jangka waktu yang diatur dalam peraturan. Namun, jika voluntary auditor switching tidak dilakukan maka auditor tidak akan berganti sebelum jangka waktu maksimal yang menyebabkan hubungan antara auditor dan klien akan semakin lama. Semakin lama auditor memberikan jasa audit kepada klien yang sama, maka pengetahuan tentang kondisi bisnis dan pengendalian internal klien akan semakin besar. Hal tersebut akan menyebabkan auditor lebih mudah untuk mendeteksi resiko termasuk untuk menilai kelangsungan usaha perusahaan sehingga kemungkinan penerimaan opini audit going concern akan semakin besar. Dalam penelitian Kim dan Lee (2015) auditor switching berpengaruh terhadap penerimaan opini audit going concern sedangkan penelitian Setiadamayanthi (2015) dan Gatot (2013) auditor switching tidak berpengaruh pada penerimaan opini audit going concern.

Likuiditas adalah kemampuan perusahaan untuk mengkonversi asetnya menjadi aset paling likuid atau kas (Subramanyam, 2014). Likuiditas bisa diukur dengan current ratio yaitu rasio yang membandingkan aset lancar (current asset) dengan kewajiban lancar (current liabilities). Rasio tersebut menggambarkan kemampuan perusahaan melunasi utang jangka pendeknya menggunakan aset lancar yang dimiliki. Nilai current ratio 
yang kecil, mengindikasikan bahwa perusahaan sedang mengalami kesulitan likuidasi dan memiliki risiko gagal bayar yang besar atas kewajibannya pada tanggal jatuh tempo. Salah satu indikasi masalah going concern adalah kegagalan pembayaran utang pada saat jatuh tempo (SA 570, IAPI 2013). Semakin kecil nilai current ratio, maka semakin besar risiko gagal bayar dan akan semakin besar pula indikasi masalah going concern sehingga meningkatkan kemungkinan penerimaan opini audit going concern. Dalam penelitian Indriastuti (2016) likuiditas berpengaruh negatif signifikan terhadap penerimaan opini audit going concern sedangkan penelitian Setiawan (2015) mengatakan bahwa likuditas tidak memiliki pengaruh terhadap penerimaan opini audit going concern.

Leverage adalah rasio yang bisa menggambarkan tingkat penggunaan utang sebagai pembiayaan perusahaan (Subramanyam, 2014). Rasio leverage dapat diukur dengan Debt to Asset Ratio (DTA). Rasio DTA menggambarkan besarnya penggunaan utang untuk membiayai aset. Semakin tinggi nilai rasio DTA menunjukkan bahwa semakin besar penggunaan utang untuk pembiayaan asetnya. Sesuai dengan SA 570, salah satu indikasi adanya masalah going concern adalah ketika perusahaan mengandalkan penggunaan utang untuk pembiayaan asetnya (IAPI, 2013). Peningkatan nilai DTA tanpa peningkatan kemampuan aset untuk menghasilkan laba akan mempersulit perusahaan dalam pembayaran beban utang pokok dan bunga sehingga memperbesar kemungkinan risiko gagal bayar. Ketika risiko gagal bayar semakin besar, maka akan timbul keraguan terhadap kemampuan perusahaan untuk mempertahankan kelangsungan usahanya sehingga meningkatkan kemungkinan penerimaan opini audit going concern perusahaan. Penelitian Setiawan (2015) mengatakan bahwa leverage yang diproksikan dengan rasio DTA berpengaruh signifikan terhadap pemberian opini audit going concern sedangkan menurut Wibisono (2013) menyatakan bahwa leverage tidak berpengaruh terhadap penerimaan opini audit going concern. 
Disclosure adalah pengungkapan, penjelasan, atau pemberian informasi oleh perusahaan yang berpengaruh atas suatu keputusan investasi (Verdiana dan Komang, 2013). Item pengungkapan laporan keuangan terbagi menjadi pengungkapan bersifat mandatory (diwajibkan) dan pengungkapan bersifat voluntary (sukarela). Item-item pengungkapan secara mandatory diatur dalam Keputusan BAPEPAM KEP431/BL/2012 tentang Penyampaian Laporan Keuangan Tahunan Emiten atau Perusahaan Publik. Perusahaan cenderung akan lebih banyak mengungkapkan informasi jika perusahaan memiliki kinerja yang baik. Namun, perusahaan dengan kinerja yang kurang baik tetap harus melakukan adequate disclosure sesuai dengan peraturan BAPEPAM KEP-431/BL/2012. Semakin banyak item disclosure yang diungkapkan, auditor akan lebih mudah untuk memahami kondisi perusahaan terutama pada perusahaan dengan kinerja yang kurang baik. Semakin besar kemampuan auditor mengidentifikasi risiko dan menilai going concern perusahaan, maka kemungkinan penerimaan opini audit going concern akan semakin besar. Penelitian yang dilakukan oleh Haris dan Merianto (2015) menyatakan bahwa disclosure berpengaruh signifikan terhadap penerimaan opini audit going concern. Sedangkan, penelitian Fahmi (2015) mengatakan bahwa disclosure tidak memiliki pengaruh terhadap penerimaan opini audit going concern.

Financial distress adalah kondisi kesulitan keuangan yang dialami oleh suatu perusahaan (Subramanyam, 2014). Sadirin (2017) menyatakan financial distress akan menyebabkan perusahaan mengalami gangguan keuangan seperti arus kas negatif, rasio keuangan yang buruk dan gagal bayar pada perjanjian utang. Perusahaan dengan kondisi financial distress berpotensi gagal membayar kewajibannya karena tidak memiliki arus kas yang cukup (Sidqi dan Sutapa, 2014). Salah satu indikasi masalah going concern menurut SA 570 adalah ketika perusahaan memiliki arus kas negatif yaitu keadaan dimana arus kas masuk lebih kecil dibandingan arus kas keluar (IAPI, 2013). Metode yang dapat digunakan untuk menilai 
kondisi financial distress adalah dengan menggunakan rasio Altman Z Score. Semakin kecil nilai Z Score menandakan bahwa perusahaan sedang berada dalam kondisi kesulitan keuangan dan berisiko tinggi pada kebangkrutan sehingga kemungkinan penerimaan opini audit going concern semakin besar. Penelitian yang dilakukan Setiadamayanthi (2016) menyatakan bahwa financial distress tidak berpengaruh terhadap penerimaan opini audit going concern. Sedangkan metode yang berbeda dilakukan oleh Stari Dewi dan Latini (2018) dengan metode Altman $Z$ Score dan menemukan hubungan negatif signifikan antara financial distress dengan opini audit going concern.

\section{Rumusan Masalah}

Berdasarkan latar belakang penelitian, rumusan masalah dalam penelitian ini adalah:

1. Apakah auditor switching berpengaruh negatif terhadap kemungkinan penerimaan opini audit going concern?

2. Apakah likuiditas yang diproksikan dengan current ratio berpengaruh negatif terhadap kemungkinan penerimaan opini audit going concern?

3. Apakah leverage yang diproksikan dengan debt to total asset ratio (DTA) berpengaruh positif terhadap kemungkinan penerimaan opini audit going concern?

4. Apakah pengungkapan laporan keuangan (disclosure) berpengaruh positif terhadap kemungkinan penerimaan opini audit going concern?

5. Apakah financial distress yang diproksikan dengan metode Altman Z Score berpengaruh negatif terhadap kemungkinan penerimaan opini audit going concern?

\section{Tujuan Penelitian}

Tujuan dari penelitian ini adalah untuk mendapatkan bukti empiris tentang:

1. Pengaruh auditor switching terhadap penerimaan opini audit going concern. 
2. Pengaruh likuiditas yang diproksikan dengan current ratio terhadap penerimaan opini audit going concern.

3. Pengaruh leverage yang diproksikan dengan debt to total asset ratio (DTA) terhadap penerimaan opini audit going concern.

4. Pengaruh disclosure yang diproksikan dengan indeks pengungkapan (disclosure) terhadap penerimaan opini audit going concern.

5. Pengaruh financial distress yang diproksikan dengan metode Altman $Z$ Score terhadap penerimaan opini audit going concern.

\section{TELAAH LITERATUR}

\section{Opini Audit Going Concern}

Berdasarkan asumsi kelangsungan usaha (going concern), suatu entitas dipandang bertahan dalam bisnis untuk masa depan yang dapat diprediksi. Laporan keuangan disusun berdasarkan suatu basis kelangsungan usaha kecuali manajemen bermaksud untuk melikuidasi entitas atau menghentikan operasinya (SA 570,
IAPI 2013). Dalam SA 570 paragraf 6, dinyatakan auditor bertanggung jawab untuk memperoleh bukti audit yang cukup dan tepat tentang ketepatan penggunaan asumsi kelangsungan usaha oleh manajemen dalam penyusunan dan penyajian laporan keuangan, dan untuk menyimpulkan apakah terdapat suatu ketidakpastian material tentang kemampuan entitas untuk mempertahankan kelangsungan usahanya. Asumsi ini mengharuskan entitas secara operasional dan keuangan memiliki kemampuan mempertahankan kelangsungan hidupnya atau going concern. Ketika melakukan prosedur penilaian risiko seperti yang diharuskan oleh SA 315, auditor harus mempertimbangkan apakah terdapat peristiwa atau kondisi yang dapat menyebabkan keraguan signifikan atas kemampuan perusahaan untuk mempertahankan kelangsungan usahanya. Kondisi yang dimaksud menurut Arens (2017) adalah:

1. Kerugian operasi atau kekurangan modal kerja yang berulang dan signifikan.

2. Ketidakmampuan perusahaan untuk membayar 
kewajibannya ketika jatuh tempo.

3. Kehilangan pelanggan utama, terjadi bencana yang tidak dijamin oleh asuransi seperti gempa bumi, banjir, atau masalah ketenagakerjaan yang tidak biasa.

4. Pengadilan, perundangundangan, atau hal-hal serupa lainnya yang sudah terjadi dan dapat membahayakan kemampuan entitas untuk beroperasi.

Dalam merumuskan opini audit mengenai going concern, auditor perlu menilai apakah terdapat pengungkapan yang memadai. Dijelaskan dalam SA 570, pengungkapan dikatakan memadai jika laporan keuangan menyajikan informasi mengenai apakah perusahaan mampu merealisasikan asetnya atau apakah perusahaan mampu melunasi kewajibannya. Jika terdapat pengungkapan yang memadai dalam laporan keuangan, maka auditor harus menyatakan opini tanpa modifikasian dan mencantumkan suatu paragraf penekanan mengenai: a. Keberadaan suatu ketidakpastian material yang berkaitan dengan peristiwa atau kondisi yang dapat menyebabkan keraguan atas kemampuan entitas untuk mempertahankan kelangsungan usahanya dan rencana manajemen

b. Mengarahkan perhatian pada catatan atas laporan keuangan yang mengungkapkan hal-hal yang dirujuk.

\section{Auditor Switching}

Auditor Switching merupakan perpindahan auditor atau KAP yang dilakukan oleh perusahaan klien (auditee) (Rustiana dan Jayanti, 2015). Pergantian auditor dapat terjadi karena merupakan suatu keharusan (mandatory) maupun secara sukarela (voluntary). Pergantian auditor secara mandatory adalah pergantian auditor yang terjadi karena regulasi yang berlaku mengenai jangka waktu pemberian jasa audit yang diatur dalam Peraturan Menteri Keuangan (PMK) No. 20 Tahun 2015 tentang Praktik Akuntan Publik yang merupakan pembaharuan dari dari PMK No. 17 
Tahun 2008. Voluntary auditor switching menyebabkan hubungan kerja auditor dengan klien lebih singkat karena pergantian auditor terjadi lebih cepat. Jika tidak terjadi voluntary auditor switching maka auditor akan diganti sesuai dengan waktu maksimal yang telah ditentukan. Semakin lama auditor memberikan jasa audit kepada klien maka pengetahuan auditor tentang kondisi klien akan semakin besar. Salah satu tahapan audit berbasis risiko adalah risk assessment atau penilaian risiko yang di dapatkan dari pengetahuan auditor tentang kondisi bisnis klien dan lingkungannya. Semakin dalam pengetahuan auditor tentang kondisi perusahaan, maka akan semakin banyak risiko-risiko yang dapat diidentifikasi pada tahap risk assessment. Semakin banyak risiko yang terdeteksi, maka auditor akan lebih mudah menilai kemampuan perusahaan untuk mempertahankan kelangsungan usahanya sebagaimana yang dijelaskan dalam SA 570. Ketika auditor lebih mampu menilai kemampuan perusahaan untuk mempertahankan kelangsungan usahanya, maka peluang pemberian opini audit going concern akan semakin besar.

$\mathrm{Ha}_{1}$ : Auditor switching berpengaruh negatif terhadap kemungkinan penerimaan opini audit going concern.

\section{Likuiditas}

Likuiditas dapat digambarkan dengan current ratio. Current Ratio merupakan perbandingan antara aset lancar dengan hutang lancar. Rasio lancar ini merupakan rasio untuk mengukur kemampuan perusahaan dalam memenuhi kewajiban jangka pendek yang segera jatuh tempo dengan menggunakan aset lancar yang tersedia (Hery, 2017). Semakin besar nilai current ratio maka semakin tinggi pula kemampuan perusahaan menggunakan aset lancar untuk melunasi kewajiban jangka pendeknya. Sebaliknya, perusahaan dikatakan kurang likuid apabila tingkat likuiditasnya kecil sehingga timbul kecenderungan perusahaan tidak dapat membayar utang jangka pendeknya. Hal tersebut akan meningkatkan risiko kegagalan pembayaran dan memperbesar peluang perusahaan menerima opini audit going concern. Seperti yang 
sudah dijelaskan dalam SA 570, contoh kondisi yang dapat menimbulkan keraguan terhadap going concern perusahaan adalah ketidakmampuan perusahaan untuk membayar para kreditur pada tanggal jatuh tempo (IAPI, 2013).

$\mathrm{Ha}_{2}$ : Likuiditas berpengaruh negatif terhadap kemungkinan penerimaan opini audit going concern.

\section{Leverage}

Subramanyam (2014) menjelaskan konsep leverage adalah suatu kondisi yang menggambarkan besarnya utang dalam struktur pendanaan suatu perusahaan. Rasio leverage dikenal juga dengan rasio solvabilitas atau rasio struktur modal (Hery, 2017). Salah satu rasio yang digunakan adalah debt to total asset ratio. Rasio DTA memberikan informasi mengenai seberapa besar penggunaan utang untuk membiayai aset perusahaan. Menurut Wibisono (2013), rasio leverage mengacu pada jumlah pendanaan yang berasal dari utang. Aset yang dibiayai dengan utang, diharapkan mampu menghasilkan laba yang lebih besar daripada nilai utangnya. Jika aset yang diperoleh tidak dapat digunakan secara efektif untuk menghasilkan laba, maka perusahaan akan mengalami kesulitan untuk membayar beban utang dan bunganya. Semakin besar nilai utang yang dimiliki akan meningkatkan keraguan auditor mengenai kemampuan perusahaan untuk mempertahankan kelangsungan usahanya karena risiko kegagalan pembayaran. Setiawan (2015) dalam penelitiannya menyatakan terdapat hubungan yang signifikan antara hubungan antara leverage dan opini audit going concern. Sedangkan menurut Wibisono (2013), tidak terdapat hubungan yang signifikan antara leverage dan opini audit going concern.

$\mathrm{Ha}_{3}$ : leverage berpengaruh positif terhadap kemungkinan penerimaan opini audit going concern.

\section{Disclosure}

Disclosure adalah pengungkapan, penjelasan, atau pemberian informasi oleh perusahaan yang berpengaruh atas suatu keputusan investasi (Verdiana dan Komang, 2013). Semakin lengkap item yang diungkapkan dalam suatu laporan keuangan dan tahunan, semakin 
lengkap pula informasi yang bisa didapatkan. Pengungkapan informasi yang semakin lengkap, akan memudahkan auditor dalam mendapatkan informasi yang digunakan untuk menilai risiko perusahaan terutama pada perusahaan dengan kinerja yang kurang baik. Semakin mudah auditor untuk menilai risiko perusahaan, maka auditor juga akan lebih mudah untuk menilai kelangsungan usaha perusahaan sehingga memperbesar pemberian opini audit going concern. Kelengkapan pengungkapan akan diukur dengan indeks disclosure yang berisikan 33 item pengungkapan sesuai dengan yang diwajibkan oleh Peraturan Badan Pengawas Pasar Modal (BAPEPAM) KEP-134/BL/2006.

$\mathrm{Ha}_{4}$ : Disclosure berpengaruh positif terhadap kemungkinan penerimaan opini audit going concern

\section{Financial Distress}

Financial distress atau kondisi kesulitan keuangan adalah kondisi yang terjadi sebelum perusahaan mengalami kebangkrutan yaitu ketika perusahaan mengalami penurunan kinerja keuangan secara terus menerus yang dikhawatirkan akan berujung pada kebangkrutan perusahaan (Dewi dan Latrini, 2018). Perusahaan yang mengalami kesulitan keuangan memiliki kemungkinan memiliki arus kas negatif, dan kegagalan membayarkan utangnya (Sadiri 2018). Terdapat metode dalam menilai financial distress yang dikenal dengan istilah model prediksi kebangkrutan. Secara umum dikenal sebagai pengukuran atas kesulitan keuangan (Wibisono, 2013). Salah satu metode yang paling sering digunakan adalah metode Altman Z Score karena dinilai lebih akurat dibandingkan hanya berdasarkan pada pendapat auditor. Model ini menggunakan lima kategori rasio keuangan yaitu likuiditas, profitabilitas, leverage, rasio pasar dan aktivitas. Klasifikasi perusahaan yang sehat dan bangkrut didasarkan pada nilai $\mathrm{Z}$ yang diperoleh, yaitu:

1. Apabila nilai $Z$-Score $<1,81$ berarti perusahaan mengalami kesulitan keuangan dengan resiko mengalami kebangkrutan yang tinggi

2. Apabila nilai $Z$-Score antara $1,81<\mathrm{Z}<2,99$ maka 
perusahaan dianggap berada pada daerah abu-abu (grey area).

3. Untuk nilai Z-Score lebih besar dari 2,9 memberikan penilaian bahwa perusahaan berada dalam keadaan yang sehat

$\mathrm{Ha}_{5}$ : Financial distress berpengaruh negatif terhadap kemungkinan penerimaan opini audit going concern.

\section{Model Penelitian}

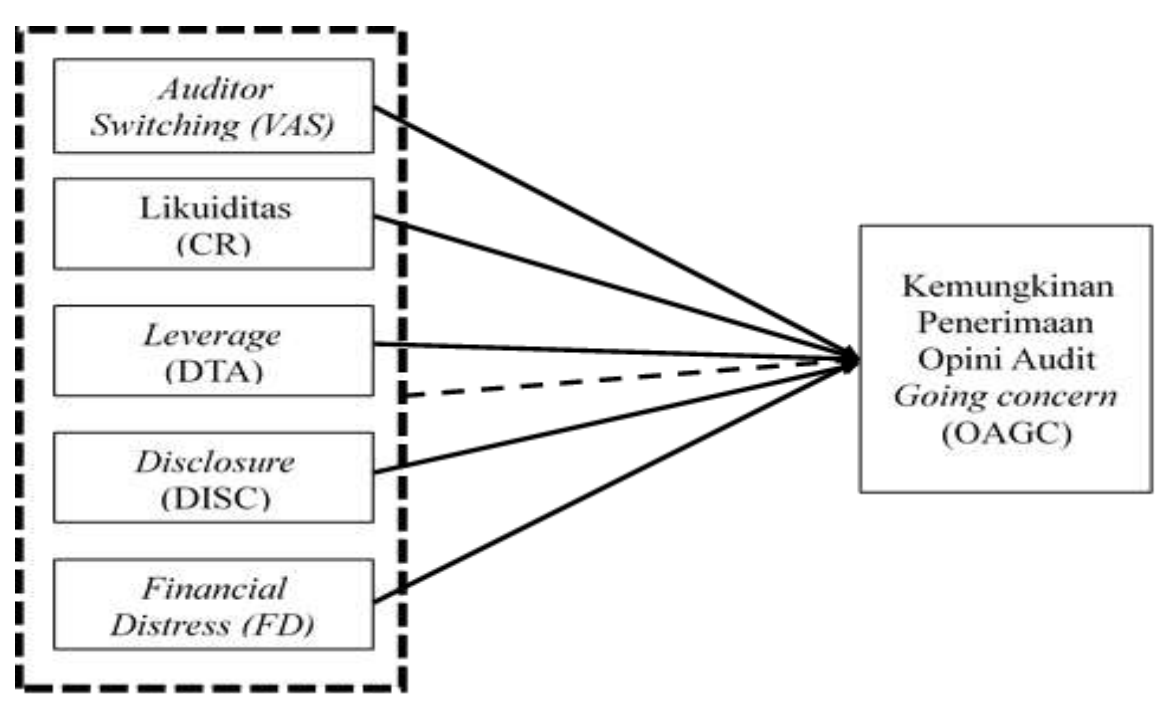

Gambar 1. Model Penelitian

\section{METODOLOGI PENELITIAN}

Gambaran Umum Objek

\section{Penelitian}

Objek penelitian yang digunakan dalam penelitian ini adalah perusahaan pertambangan yang terdaftar di Bursa Efek Indonesia. Periode penelitian yang akan diteliti adalah selama empat tahun dari tahun 2013 sampai tahun 2016.

\section{Metode Penelitian}

Penelitian ini merupakan penelitian dengan hubungan sebab akibat (causal study). Causal study adalah penelitian yang dilakukan untuk menguji apakah suatu variabel menyebabkan perubahan pada variabel lain (Sekaran dan Bougie, 2016). Causal study berguna untuk mengukur hubungan-hubungan antar variabel penelitian atau berguna 
untuk menganalisis bagaimana suatu variabel mempengaruhi variabel lain (Sekaran dan Bougie, et al. 2016).

\section{Variabel Penelitian}

Variabel penelitian yang digunakan dalam penelitian ini adalah variabel terikat atau variabel dependen $(\mathrm{Y})$ dan variabel bebas atau variabel independen (X). Variabel dalam penelitian ini terdiri atas satu variabel dependen dan empat variabel independen. Variabel dependen dalam penelitian ini adalah sebagai berikut.

\section{Opini Audit Going Concern}

Dalam penelitian ini opini audit going concern diukur dengan variabel dummy. Skor 1 akan diberikan kepada sampel yang menerima opini audit going concern dan skor 0 untuk sampel yang tidak menerima opini audit going concern.

\section{Auditor Switching}

Dalam Penelitian ini, auditor switching diukur dengan variabel dummy. Skor 1 akan diberikan kepada sampel yang melakukan voluntary auditor switching dan skor 0 untuk sampel yang tidak melakukan voluntary auditor switching.

\section{Likuiditas}

Dalam penelitian ini, variabel likuiditas diukur dengan current ratio. Menurut Subramanyam (2014), current ratio dirumuskan sebagai berikut:

$$
\text { Current } \text { Ratio }=\frac{\text { Current Asset }}{\text { Current Liability }}
$$

Keterangan:

Current Asset : Total Aset Lancar

Current Liability $\quad$ : Total Kewajiban Lancar

\section{Leverage}

Dalam penelitian ini, variabel leverage diproksikan dengan Debt to
Total Asset Ratio (DTA). Mneurut Subramanyam (2014) DTA dirumuskan sebagai berikut:

$$
D T A=\frac{\text { Total Debt }}{\text { Total Asset }}
$$

Keterangan: 
Pengaruh Auditor Switching, Likuiditas, Leverage, Disclosure dan Financial Distress

Terhadap Kemungkinan Penerimaan Opini Audit Going Concern

DTA : Debt to total asset ratio

Total debt : : Total utang

Total equity : Total ekuitas

\section{Disclosure}

Dalam penelitian ini, disclosure akan diukur dengan indeks disclosure dan item pengungkapan disesuaikan dengan KEP BAPEPAM134/BL/2006 dengan skor maksimal 33. Indeks disclosure menurut Fahmi (2015) dirumuskan sebagai berikut:

Indeks disclosure $=\frac{\text { Jumlah skor disclosure yang dipenuhi }}{\text { Jumlah skor maksimum }}$

\section{Financial Distress}

Dalam penelitian ini, financial Score dalam Subramanyam (2014)

distress diukur dengan Altman $Z$ yang dirumuskan sebagai berikut:

$$
Z=1,2 Z_{1}+1,4 Z_{2}+3,3 Z_{3}+0,6 Z_{4}+1 Z_{5}
$$

Keterangan:

$\mathrm{Z}=$ Altman Z Score

Z1 = Net Working Capital (Current Asset - Current Liabilities / Total Asset)

Z2 = Retained Earning to Total Asset (Retained Earning / Total Asset)

$\mathrm{Z3}=$ Earning before interest and taxes / Total Asset

$\mathrm{Z4}=$ Market value of equity/Total Debt

$\mathrm{Z} 5$ = Sales $/$ Total Sales 
Teknik Pengumpulan Data

Data yang digunakan dalam penelitian ini adalah data sekunder (secondary data) yaitu data atau informasi yang dikumpulkan oleh orang lain selain peneliti saat ini (Sekaran dan Bougie, 2016). Data sekunder dalam penelitian ini berupa laporan keuangan (financial report) yang disajikan dalam mata uang rupiah untuk tahun-tahun yang berakhir pada 31 Desember dan telah diaudit dari perusahaan manufaktur yang terdaftar di Bursa Efek Indonesia (BEI) periode tahun 20132016. Data yang dikumpulkan berasal dari situs resmi Bursa Efek Indonesia, www.idx.co.id.

\section{Teknik Pengambilan Sampel}

Metode yang digunakan untuk pengambilan sampel adalah purposive sampling. Purposive sampling adalah metode pemilihan sampel berdasarkan kriteria yang telah ditentukan sebelumnya (Sekaran dan Bougie, 2016). Kriteria yang digunakan dalam pengambilan sampel dalam penelitian ini adalah sebagai berikut:

1. Perusahaan sektor pertambangan yang terdaftar secara berturut-turut di Bursa Efek Indonesia (BEI) selama periode 2013-2016

2. Menerbitkan laporan tahunan dan laporan keuangan dengan periode 1 Januari hingga 31 Desember yang telah di audit dan disajikan dalam mata uang rupiah

3. Perusahaan yang mengalami rugi tahun berjalan minimal dua periode berturut-turut antara tahun 2013-2016.

\section{Uji Hipotesis}

\section{Analisis Regresi Logistik}

Dalam penelitian ini, teknik uji hipotesis yang digunakan adalah analisis multivariat dengan menggunakan regresi logistik yang variabel bebasnya merupakan kombinasi antara metrik dan non metrik (kategorial). Regresi logistik ini digunakan untuk menguji apakah probabilitas terjadinya variabel dependen dapat diprediksi dengan variabel independen. Pada teknik analisa regresi logistik tidak lagi memerlukan uji normalitas dan uji asumsi klasik pada variabel bebasnya (Ghozali, 2016). Model regresi 
logistik yang digunakan untuk menguji hipotesis sebagai berikut:

$$
\operatorname{Ln} \frac{\mathrm{GC}}{1-\mathrm{GC}}=\alpha+\beta 1 \mathrm{VAS}+\beta_{2} \mathrm{CR}+\beta_{3} \mathrm{DTA}+\beta_{4} \mathrm{DISC}+\beta_{5} \mathrm{FD}
$$

Keterangan :

Ln $\frac{\mathrm{GC}}{1-\mathrm{GC}} \quad$ : Opini Audit Going concern

(variabel dummy, 1 jika mendapat opini going concern, 0 jika mendapat opini non going concern)

$\alpha \quad$ : Konstanta

VAS : Voluntary auditor Switching

(variabel dummy, 1 jika melakukan voluntary auditor switching dan 0 jika tidak melakukan voluntary auditor switching)

CR : Likuiditas, menggunakan Current Ratio

DTA : Leverage, menggunakan Debt to Total Asset Ratio

DISC : Disclosure, menggunakan indeks disclosure level

FD : Financial Distress, menggunakan Revised Altman Z Score

\section{Uji Statistik Deskriptif}

Statistik deskriptif merupakan uji yang memberikan gambaran atau deskripsi suatu data yang dilihat dari nilai rata-rata (mean), standar deviasi, maksimum, minimum, range, (Ghozali, 2016). Tujuan statistik deskriptif adalah untuk melihat penyebaran data yang ada. Mean adalah jumlah seluruh data yang ada dibagi dengan banyaknya data. Standar deviasi adalah suatu ukuran penyimpangan atas data yang diteliti. Minimum dan maksimum adalah nilai terkecil dan terbesar dari data yang diuji. Range merupakan selisih nilai maksimum dan minimum.

\section{Uji Model Fit}

Uji ini digunakan untuk menilai apakah model yang telah dihipotesiskan telah fit dengan data. Statistik yang digunakan berdasarkan -2 Log Likehood value (nilai 2LogL). Likehood $L$ dari model adalah probabilitas bahwa model yang dihipotesiskan menggambarkan data yang di input. Penurunan nilai $\log$ Likehood pada uji ini menunjukkan bahwa model regresi semakin baik (Ghozali, 2016). 


\section{Uji Koefisien Determinasi}

Koefisien determinasi merupakan uji yang menunjukan kemampuan dari variabel independen (X) dalam menjelaskan variabel dependen (Y). Koefisien determinasi pada regresi logistik dapat dilihat dari besaran nilai Nagelkerke's $R \quad$ Square). Nagelkerke $R$ Square merupakan pengujian yang dilakukan untuk mengetahui seberapa besar variabel independen mampu menjelaskan dan mempengaruhi variabel dependen. Jika nilai signifikansi semakin mendekati nilai 1 maka model dianggap semakin fit karena variabel independen dan variabel dependen mempunyai hubungan yang semakin kuat. Sementara semakin mendekati 0 maka model akan dinilai semakin tidak fit (Ghozali, 2016).

\section{Uji Kelayakan Model Regresi}

Uji kelayakan model regresi dinilai menggunakan Hosmer and Lemeshow's Goodness of Fit Test. Uji ini digunakan untuk menguji hipotesis nol bahwa data empiris sesuai dengan model (tidak ada perbedaan antara model dengan data sehingga model dikatakan fit). Adapun hasilnya jika nilai signifikansi dari Hosmer and Lemeshow's Goodness of Fit Test lebih besar dari 0,05 maka dapat dikatakan bahwa model dapat diterima sesuai data observasinya sehingga model regresi layak digunakan untuk analisis selanjutnya karena tidak ada perbedaan yang signifikan antara model dengan nilai observasinya. Sedangkan jika nilai signifikansi dari Hosmer and Lemeshow's Goodness of Fit Test sama atau kurang dari 0,05 maka terdapat perbedaan signifikan antara model dengan nilai observasinya sehingga model dinilai tidak baik.

\section{Tabel Klasifikasi}

Tabel klasifikasi menunjukkan kekuatan prediksi dari model regresi untuk memprediksi kemungkinan penerimaan opini audit going concern. Dalam output regresi logistic, hasil dapat dilihat pada classification table.

\section{Uji Signifikansi Simultan (Omnibus Test of Model Coefficient)}


Uji signifikansi simultan dilakukan dengan menggunakan Omnibus Test of Model Coefficient. Uji ini dilakukan untuk menguji pengaruh seluruh variabel independen secara bersama-sama terhadap variabel dependen. Variabel independen dikatakan berpengaruh secara simultan pada variabel dependen jika nilai signifikansinya lebih kecil dari 0,05 .

\section{HASIL \& ANALISIS}

Tabel 1. Rincian Pengambilan Sampel Penelitian

\begin{tabular}{llc}
\hline No & Kriteria & $\begin{array}{c}\text { Jumlah } \\
\text { Perusahaan }\end{array}$ \\
\hline 1 & $\begin{array}{l}\text { Terdaftar sebagai perusahaan pertambangan di Bursa } \\
\text { Efek Indonesia (BEI) secara berturut-turut selama } \\
\text { periode 2013-2016 }\end{array}$ & 41 \\
& $\begin{array}{l}\text { Menerbitkan laporan tahunan dan laporan keuangan } \\
\text { dengan periode 1 Januari hingga 31 Desember yang } \\
\text { telah di audit dan disajikan dalam mata uang rupiah }\end{array}$ & 14 \\
$3 \quad \begin{array}{l}\text { Mengalami rugi tahun berjalan minimal 2 tahun } \\
\text { berturut-turut selama periode penelitian }\end{array}$ & 8 \\
Perusahaan yang digunakan sebagai sampel dalam \\
penelitian
\end{tabular}

\section{Statistik Deskriptif}

Tabel 2. Hasil Statistik Deskriptif

Descriptive Statistics

\begin{tabular}{|l|r|r|r|r|r|r|}
\hline & \multicolumn{1}{|c|}{$\mathrm{N}$} & \multicolumn{1}{c|}{ Range } & Minimum & Maximum & \multicolumn{1}{c|}{ Mean } & Std. Deviation \\
\hline CR & 32 & 76.9076 & .2656 & 77.1732 & 6.336425 & 13.9932962 \\
DTA & 32 & .6394 & .0074 & .6468 & .350378 & .1949876 \\
DISC & 32 & .5450 & .4550 & 1.0000 & .839906 & .1282780 \\
FD & 32 & 78.1278 & -1.9432 & 76.1846 & 8.702566 & 15.4912265 \\
Valid N (listwise) & 32 & & & & & \\
\hline
\end{tabular}

Berdasarkan hasil uji statistik deskriptif pada Tabel 2, Variabel likuiditas $(C R)$ memiliki nilai ratarata (mean) sebesar 6,336425. Hal ini menunjukkan bahwa rata-rata sampel memiliki 1 Rupiah utang lancar yang dijaminkan oleh 6,3364 Rupiah aset lancar sehingga kemampuan untuk melunasi utang lancarnya besar. Variabel Leverage (DTA) memiliki rata- rata (mean) sebesar 0,350378. Hal tersebut menunjukkan bahwa $35,38 \%$ aset dibiayai oleh utang. Hal ini menunjukkan rata-rata sampel 
lebih banyak menggunakan ekuitas untuk pemodalan asetnya. Variabel disclosure (DISC) memiliki nilai rata-rata (mean) sebesar 0,839906. Hal tersebut menunjukkan bahwa rata- rata perusahaan sampel telah memenuhi 83,99\% item disclosure atau 27 item dari 33 item yang diwajibkan. Variabel financial distress memiliki nilai rata-rata (mean) sebesar 8,70256. Hal tersebut menunjukkan bahwa rata- rata sampel memiliki kondisi keuangan yang sehat karena nilainya lebih besar dari 2,99.

Tabel 3. Hasil Uji Frekuensi Variabel Opini Audit Going Concern

\begin{tabular}{|ll|r|r|r|r|}
\multicolumn{7}{|c|}{ OAGC } \\
\hline & & Frequency & Percent & Valid Percent & $\begin{array}{c}\text { Cumulative } \\
\text { Percent }\end{array}$ \\
\hline Valid & TIDAK & 24 & 75.0 & 75.0 & 75.0 \\
& YA & 8 & 25.0 & 25.0 & 100.0 \\
& Total & 32 & 100.0 & 100.0 & \\
\hline
\end{tabular}

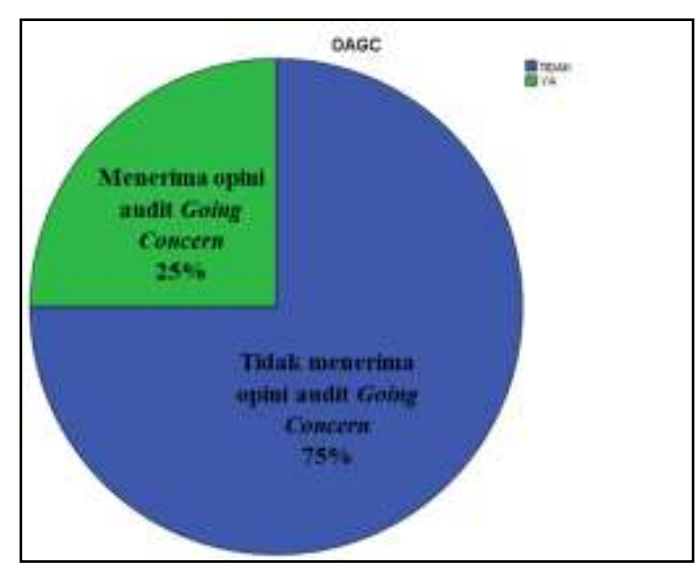

Gambar 2. Pie Chart Variabel Dependen Opini Audit Going Concern

Berdasarkan Tabel 3 dan Gambar 2, jumlah perusahaan sektor pertambangan yang terdaftar di Bursa Efek Indonesia tahun 20132016 yang menerima opini audit going concern adalah sebanyak 8 data atau sebanyak $25 \%$ dari total 32 data sampel. Sedangkan, sampel yang tidak menerima opini audit going concern adalah sebanyak 24 data atau sebesar $75 \%$ dari total 32 data sampel. Perusahaan yang menerima opini audit going concern dalam penelitian ini adalah PT Cita 
Mineral Investindo (CITA) tahun 2016 , dan PT Mitra Investindo 2013-2016, PT Barajaya (MITI) tahun 2015-2016.

Internasional (ATPK) tahun 2015-

Tabel 4. Hasil Uji Frekuensi Variabel Auditor Switching

\begin{tabular}{|c|c|c|c|c|c|}
\hline \multicolumn{6}{|c|}{ VAS } \\
\hline & & Frequency & Percent & Valid Percent & $\begin{array}{c}\text { Cumulative } \\
\text { Percent }\end{array}$ \\
\hline \multirow[t]{3}{*}{ Valid } & TIDAK & 19 & 59.4 & 59.4 & 59.4 \\
\hline & YA & 13 & 40.6 & 40.6 & 100.0 \\
\hline & Total & 32 & 100.0 & 100.0 & \\
\hline
\end{tabular}

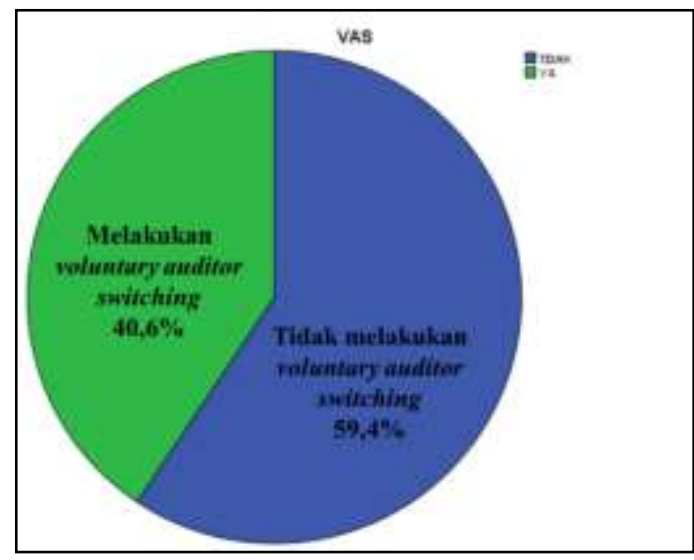

Gambar 3. Pie Chart Variabel Auditor Switching

Berdasarkan Tabel 4 dan Gambar 3, perusahaan pertambangan yang terdaftar di BEI tahun 2013-2016 yang melakukan voluntary auditor switching sebanyak 13 (40,6\% dari data sampel yang diteliti). Sedangkan perusahaan yang tidak melakukan auditor switching adalah sebanyak 19 atau sebesar $59,4 \%$ dari 32 data sampel. Perusahaan pertambangan yang melakukan voluntary auditor switching adalah PT Aneka Tambang (ANTM) tahun 2016, PT Barajaya Resources (ATPK) tahun 2015, PT Cita Mineral (CITA) tahun 2016, PT Cakra Mineral (CKRA) tahun 20142015, PT Perdana Karya Perkasa (PKPK) tahun 2013,2015, 2016, dan PT Golden Eagle Energy (SMMT) tahun 2015.

\section{Uji Model Fit (Overall Model Fit)}

Tabel 5. Nilai -2LogL Awal (Block Number=0) 
Iteration History ${ }^{\mathrm{a}, \mathrm{b}, \mathrm{c}}$

\begin{tabular}{|c|c|c|c|}
\hline \multirow{2}{*}{\multicolumn{2}{|c|}{ Iteration }} & \multirow{2}{*}{$\begin{array}{c}-2 \mathrm{Log} \\
\text { likelihood }\end{array}$} & Coefficients \\
\hline & & & Constant \\
\hline \multirow[t]{4}{*}{ Step 0} & 1 & 36.049 & -1.000 \\
\hline & 2 & 35.989 & -1.096 \\
\hline & 3 & 35.989 & -1.099 \\
\hline & 4 & 35.989 & -1.099 \\
\hline
\end{tabular}

Tabel 6. Nilai -2LogL Akhir (Block Number=1)

\begin{tabular}{|c|c|c|c|c|c|c|c|c|}
\hline \multicolumn{9}{|c|}{ Iteration History ${ }^{\mathrm{a}, \mathrm{b}, \mathrm{c}, \mathrm{d}}$} \\
\hline \multirow{2}{*}{\multicolumn{2}{|c|}{ Iteration }} & \multirow{2}{*}{$\begin{array}{l}-2 \text { Log } \\
\text { likelihood }\end{array}$} & \multicolumn{6}{|c|}{ Coefficients } \\
\hline & & & Constant & VAS & CR & DTA & DISC & FD \\
\hline Step 1 & 1 & 26.214 & -1.205 & -.578 & .047 & 5.198 & -1.735 & -.025 \\
\hline & 2 & 22.426 & -3.201 & -1.053 & .103 & 9.572 & -1.673 & -.062 \\
\hline & 3 & 21.269 & -4.965 & -1.232 & .167 & 12.747 & -1.341 & -.118 \\
\hline & 4 & 20.857 & -5.643 & -1.143 & 277 & 13.457 & -.984 & -.238 \\
\hline & 5 & 20.620 & -5.569 & -.991 & .461 & 12.862 & -.792 & -.441 \\
\hline & 6 & 20.582 & -5.467 & -1.004 & .551 & 12.815 & -.870 & -.545 \\
\hline & 7 & 20.580 & -5.415 & -1.008 & .559 & 12.770 & -.886 & -.564 \\
\hline & 8 & 20.580 & -5.389 & -1.006 & .556 & 12.731 & -.887 & -.567 \\
\hline & 9 & 20.580 & -5.385 & -1.006 & .555 & 12.724 & -.887 & -.567 \\
\hline & 10 & 20.580 & -5.385 & -1.006 & .555 & 12.724 & -.887 & -.567 \\
\hline
\end{tabular}

Pada Tabel 5 diperoleh hasil -2 $\log L$

Awal (Block Number $=0$ ) sebesar 35,989. Nilai ini merupakan nilai yang diperoleh saat konstanta dimasukan ke dalam model penelitian tanpa memperhitungkan variabel independen. Kemudian pada Tabel 6 diperoleh nilai $-2 \quad \log L$ Akhir (Block Number $=1)$ sebesar 20,580 setelah menambahkan variabel independen yaitu Auditor switching (AS), Likuiditas (CR), Leverage (DTA), Disclosure (DISC) dan Financial distress (FD). Selisih $2 \log L$ awal dengan $-2 \log L$ akhir adalah sebesar 15,049. Untuk mengetahui penurunan nilai $-2 \log \mathrm{L}$, selisih 15,409 (35,989 - 20,580) lebih besar dari tabel biometri signifikansi dengan $d f 5$ yaitu sebesar 2,571 maka model dikatakan fit dengan data. 


\section{Uji Koefisien Determinasi (Nagelkerke's $R$ Square)}

Tabel 7. Hasil Uji Koefisien Determinasi

Model Summary

\begin{tabular}{|l|ll|l|l|}
\hline Step & -2 & Log & Cox \& Snell R \\
likelihood & Square & Square \\
\hline 1 & $20.580^{\mathrm{a}}$ & .382 & .566 \\
\hline
\end{tabular}

a. Estimation terminated at iteration number 10 because parameter estimates changed by less than .001 .

Hasil dari uji koefisien determinasi pada Tabel 7 menunjukkan angka Nagelkerke's $R$ Square sebesar 0,566 . Hal ini menunjukkan bahwa variabel independen yaitu auditor switching, likuiditas, leverage, disclosure dan financial distress dapat menjelaskan variabel dependen penerimaan opini audit going concern sebesar $56,6 \%$ dan $43,4 \%$ lainnya dijelaskan oleh variabel lain diluar variabel dalam penelitian ini.

\section{Uji Kelayakan Model Regresi}

Tabel 8. Hasil Uji Kelayakan Model Regresi

\section{Hosmer and Lemeshow Test}

\begin{tabular}{|c|c|c|c|}
\hline Step & Chi-square & df & Sig. \\
\hline 1 & 9.207 & 8 & .325 \\
\hline
\end{tabular}

Berdasarkan Tabel 8 diperoleh hasil signifikansi sebesar 0,325 yang lebih besar dari tingkat signifikan yaitu 0,05. Maka dari hasil tersebut hipotesis $\mathrm{H}_{0}$ diterima karena model mampu memprediksi nilai observasinya. Dengan demikian, dapat disimpulkan bahwa model penelitian dapat diterima. 


\section{Tabel Klasifikasi}

Tabel 9. Tabel Klasifikasi

Classification Table ${ }^{a}$

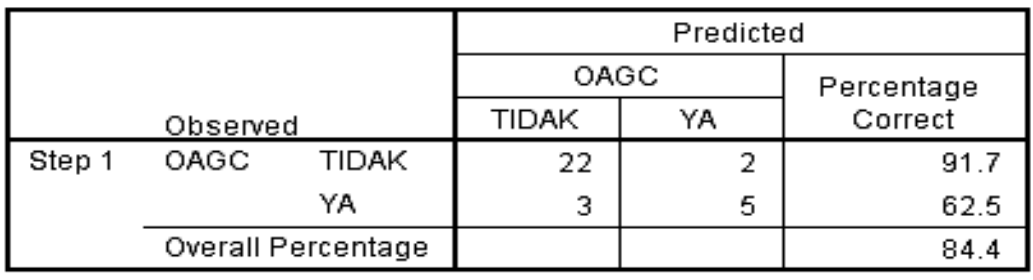

a. The cut value is .500

Tabel 9 menunjukkan kemampuan model regresi untuk memprediksi penerimaan opini audit going concern adalah $62,5 \%$ atau model regresi mampu memprediksi 5 dari total 8 perusahaan. Selain itu, kemampuan model regresi untuk memprediksi kemungkinan tidak menerima opini audit going concern adalah sebesar $91,7 \%$. Secara keseluruhan, kemampuan prediksi adalah sebesar $84,4 \%$.

\section{Uji Signifikansi Simultan}

Tabel 10. Hasil Uji Signifikansi Simultan

\section{Omnibus Tests of Model Coefficients}

\begin{tabular}{|ll|c|c|c|}
\hline & & Chi-square & df & Sig. \\
\hline \multirow{4}{*}{ Step 1 } & Step & 15.410 & 5 & .009 \\
& Block & 15.410 & 5 & .009 \\
& Model & 15.410 & 5 & .009 \\
\hline
\end{tabular}

Berdasarkan Tabel 10, diperoleh hasil uji simultan dengan nilai chisquare sebesar 15,410 dan nilai signifikansi sebesar 0,009 yang lebih kecil dari tingkat signifikansi 0,05. Sehingga dapat disimpulkan bahwa variabel independen dalam penelitian ini yaitu auditor switching, likuiditas, leverage, disclosure, dan financial distress secara simultan berpengaruh signifikan terhadap kemungkinan penerimaan opini audit going concern. 


\section{Uji Hipotesis}

Tabel 11. Hasil Uji Hipotesis

\begin{tabular}{|c|r|r|r|r|r|r|}
\hline \multicolumn{1}{|c|}{ Variables in the Equation } \\
& \multicolumn{1}{|c|}{ B } & \multicolumn{1}{c|}{ S.E. } & Wald & \multicolumn{1}{c|}{ df } & \multicolumn{1}{c|}{ Sig. } & \multicolumn{1}{c|}{ Exp(B) } \\
\hline Step 1 ${ }^{\text {a }}$ VAS & -1.006 & 1.424 & .499 & 1 & .480 & .366 \\
CR & .555 & .720 & .595 & 1 & .441 & 1.742 \\
DTA & 12.724 & 7.591 & 2.810 & 1 & .094 & 335754.316 \\
DISC & -.887 & 4.233 & .044 & 1 & .834 & .412 \\
FD & -.567 & .722 & .617 & 1 & .432 & .567 \\
Constant & -5.385 & 5.620 & .918 & 1 & .338 & .005 \\
\hline
\end{tabular}

Berdasarkan tabel 11, variabel auditor switching memiliki nilai koefisien regresi sebesar -1,006 yang menunjukkan bahwa setiap kenaikan satu satuan variabel voluntary auditor switching akan mengurangi kemungkinan penerimaan opini audit going concern sebesar 1,006 dan penurunan satu satuan voluntary auditor switching akan meningkatkan kemungkinan penerimaan opini audit going concern sebesar 1,006. Tingkat signifikansi yang diperoleh adalah sebesar 0,480 yang lebih besar dari 0,05 sehingga $\mathrm{Ha}_{1}$ ditolak. Maka dapat disimpulkan bahwa auditor switching secara voluntary tidak berpengaruh terhadap kemungkinan penerimaan opini audit going concern. Hal ini sejalan dengan penelitian yang dilakukan Setiadamayanthi (2016) dan Gatot (2014). Voluntary auditor switching tidak berpengaruh terhadap kemungkinan penerimaan opini audit going concern karena setiap auditor pengganti harus mematuhi standar audit yang berlaku termasuk standar audit mengenai kelangsungan usaha. Dalam standar audit 570 dijelaskan beberapa indikasi masalah going concern dan bagaimana auditor harus mengungkapkannya. Jika ditemukan indikasi dan auditor memiliki keraguan, maka auditor tetap harus memberikan opini audit mengenai going concern. Maka opini audit yang diberikan oleh auditor baru maupun auditor lama akan cenderung sama karena terdapat standar audit yang harus dipatuhi oleh keduanya.

Variabel likuiditas yang diproksikan dengan current ratio memiliki nilai koefisien regresi sebesar 0,555 dan nilai signifikansi sebesar 0,441 . Nilai koefisien regresi positif menandakan 
bahwa setiap kenaikan satu satuan variabel likuditas akan meningkatkan kemungkinan penerimaan opini audit going concern sebesar 0,555 dan setiap penurunan satu satuan likuiditas juga akan mengurangi kemungkinan penerimaan opini audit going concern sebesar 0,555. Sedangkan, nilai signifikansi yang lebih besar dari 0,05 menunjukkan bahwa $\mathrm{Ha}_{2}$ ditolak. Hasil penelitian ini sejalan dengan hasil penelitian Setiawan (2015) yang membuktikan bahwa likuiditas yang diproksikan dengan current ratio tidak berpengaruh terhadap penerimaan opini audit going concern. Likuiditas tidak berpengaruh terhadap kemungkinan penerimaan audit going concern karena rata-rata presentase komposisi aset lancar berasal dari Kas dan Setara Kas. Karena sifatnya yang sangat likuid, Kas dan Setara Kas dapat dengan mudah digunakan untuk menunjang kegiatan operasional perusahaan sehingga mengurangi kemungkinan pemberian opini audit going concern. Variabel leverage yang diproksikan dengan Debt to total asset ratio (DTA) memiliki koefisien regresi sebesar 12,724 dengan nilai signifikansi 0,094. Nilai koefisien regresi positif menandakan bahwa setiap kenaikan satu satuan leverage akan meningkatkan kemungkinan penerimaan opini audit going concern sebesar 12,724 dan penurunan satu satuan leverage akan mengurangi kemungkinan penerimaan opini audit going concern sebesar 12,724. Sedangkan nilai signifikansi yang lebih besar dari 0,05 menunjukkan bahwa $\mathrm{Ha}_{3}$ ditolak. Hasil penelitian ini sejalan dengan penelitian Wibisono (2013) yang menyatakan bahwa leverage yang diproksikan dengan debt to total asset ratio tidak berpengaruh terhadap penerimaan opini audit going concern. Utang sendiri terbagi menjadi dua jenis yaitu utang jangka pendek dan utang jangka panjang. Sampel memiliki tren peningkatan DTA yang diiringi dengan peningkatan utang. Namun, utang yang meningkat lebih besar berasal dari peningkatan long-term debt dibandingkan dengan short-term debt. Semakin lama waktu jatuh tempo, akan memberikan lebih banyak waktu bagi perusahaan mengumpulkan sejumlah dana untuk pembayaran utangnya. Maka 
perusahaan memiliki kemampuan yang lebih besar untuk melunasi utang dengan waktu jatuh tempo yang panjang sehingga mengurangi resiko gagal bayar.

Variabel disclosure pada penelitian ini memperoleh nilai koefisien regresi sebesar $-0,887$ dan nilai signifikansi sebesar 0,834 . Nilai koefisien regresi negatif menunjukkan bahwa setiap kenaikan satu satuan variabel disclosure akan mengurangi kemungkinan penerimaan opini audit going concern sebesar 0,877 dan penurunan satu nilai disclosure akan meningkatkan kemungkinan penerimaan opini audit going concern. Sementara itu, nilai signifikansi yang lebih besar dari 0,05 menandakan bahwa $\mathrm{Ha}_{4}$ ditolak. Hasil penelitian ini sejalan dengan penelitian yang dilakukan Fahmi (2015) bahwa disclosure tidak berpengaruh terhadap penerimaan opini audit going concern. Hal ini disebabkan karena seluruh sampel dengan nilai disclosure diatas ratarata mengungkapkan item mengenai prospek usaha yang menjadi pertimbangan auditor bahwa perusahaan memiliki kemampuan bertahan di masa yang akan datang. Variabel financial distress yang diproksikan dengan Altman Z Score memiliki nilai koefisien regresi 0,567 dengan nilai signifikansi sebesar 0,432. Nilai koefisien regresi negatif menunjukkan bahwa setiap kenaikan satu satuan variabel financial distress akan mengurangi kemungkinan pemberian opini audit going concern sebesar 0,567 dan penurunan satu satuan nilai financial distress akan meningkatkan kemungkinan pemberian opini audit going concern. Sementara itu, nilai signifikansi yang lebih besar dari 0,05 menunjukkan bahwa $\mathrm{Ha}_{5}$ ditolak. Hal ini bertentangan dengan penelitian yang dilakukan oleh Dewi dan Latrini (2018) yang menyatakan bahwa financial distress berpengaruh terhadap penerimaan opini audit going concern. Hasil uji statistik deskriptif menunjukkan bahwa ratarata sampel dalam penelitian memiliki nilai $Z$ Score yang lebih besar dari 2,99 sehingga sampel yang diteliti memiliki kondisi keuangan yang sehat. Nilai $\mathrm{Z}$ terbesar didapatkan dari rasio Market Value to Book Value of Total Debt (Z4). $\mathrm{Z}_{4}$ 
adalah rasio yang menggambarkan kemampuan perusahaan untuk menjaminkan total utangnya menggunakan modal ekuitas yang didapat dari saham. . Besarnya nilai $\mathrm{Z}_{4}$ mengindikasikan bahwa masih terdapat kepercayaan investor yang di tandai dengan harga dan volume lembar saham yang laku terjual di pasar saham. Ketika perusahaan masih bisa mendapatkan modal dari investor, maka perusahaan akan memiliki dana yang dapat digunakan untuk kegiatan operasionalnya sehingga kelangsungan usaha perusahaan dapat dipertahankan di masa depan.

\section{KESIMPULAN}

\section{Simpulan}

Penelitian ini menguji pengaruh auditor switching, likuiditas, leverage, disclosure dan financial distress terhadap kemungkinan penerimaan opini audit going concern. Berdasarkan serangkaian pengujian yang dilakukan, diperoleh hasil penelitian sebagai berikut:

1. Variabel auditor switching, likuiditas, leverage, disclosure dan financial distress tidak berpengaruh terhadap kemungkinan penerimaan opini audit going concern.

\section{Keterbatasan}

Keterbatasan dari penelitian ini diantaranya:

1. Jumlah sampel sektor pertambangan yang sedikit

2. Nilai koefisien determinasi yang hanya sebesar $56,6 \%$ menandakan bahwa variabel independen yang digunakan hanya mampu mempengaruhi variabel dependen sebesar $56,6 \%$ dan $43,4 \%$ lainnya dijelaskan oleh variabel lain.

\section{Saran}

Saran untuk penelitian selanjutnya terkait dengan topik mengenai kemungkinan penerimaan opini audit going concern adalah memperluas sektor industri ataupun menambah variabel independen lain seperti audit tenure, kualitas auditor, opini audit tahun sebelumnya, voluntary disclosure serta variabel lain yang memiliki kemungkinan dapat mempengaruhi kemungkinan penerimaan opini audit going concern. 


\section{DAFTAR PUSTAKA}

Arens, A. A., Randal J. E., dan Mark S. B. 2017. Auditing and Assurance Services, Global Edition, 16/E, New Jersey: Pearson.

Badan Pengawas Pasar Modal dan Lembaga Keuangan (BAPEPAM). 2012. Keputusan Kementrian Keuangan Republik Indonesia Nomor: KEP-431/BL/2012 tentang Penyampaian Laporan Tahunan Emiten Atau Perusahaan Publik.

Dewi, I Dewa Ayu Nyoman Stari dan Made Yenni Latrini. 2018. "Pengaruh Financial Distress dan Debt Default pada Opini Audit Going concern". EJurnal Akuntansi Universitas Udayana Vol. 22.

Fahmi, M. Nur. 2015. "Pengaruh Audit Tenure, Opini Audit Tahun Sebelumnya, Dan Disclosure Terhadap Opni Audit Going Concern". Vol. VIII No. 3, (162-170).
Forddanta, H. Dityasa. (28 November 2017). Borneo Lumbung berada di ujung tanduk. Kontan.co.id. Diakses pada 3 Agustus 2018, dari https://investasi.kontan.co.id/n ews/borneo-lumbung-beradadi-ujung-tanduk.

Ghozali, Imam. 2016. Aplikasi Analisis Multivariate Dengan Program IBM SPSS 23 Edisi Kedelapan. Badan Penerbit Universitas Diponegoro.

Harris, Randy dan Wahyu Merianto. 2015. "Pengaruh Debt Default, Disclosure, Opini Audit Tahun Sebelumnya, Ukuran Perusahaan, dan Oppinion Shopping Terhadap Penerimaan Opini Audit Going Concern". Diponegoro Journal of Accounting Vol. 4 No. 3.

Hary. 2017. Auditing dan Asurans (Pemeriksaan Akuntansi Berbasis Standar Audit Internasional). Jakarta: Grasindo.

Ikatan Akuntan Indonesia (IAI). (2016). Standar Akuntansi Keuangan. Jakarta.

Indriastuti, Maya. 2016. "Pengaruh Profitabilitas dan Likuiditas terhadap Penerimaan Opini Audit Going concern (The Effect of Profitability and Liquidity acceptance of Audit Opinion Going concern)". Fokus Ekonomi Vol. 11 No. 2 $(37-50)$. 
Institut Akuntan Publik Indonesia (IAPI). 2013. Standar Audit (SA) Seksi 315: Pengidentifikasian dan Penilaian Risiko Kesalahan Penyajian Material Melalui Pemahaman Atas Entitas dan Lingkungannya. Jakarta: IAPI.

Institut Akuntan Publik Indonesia (IAPI). 2013. Standar Audit (SA) Seksi 700: Perumusan Suatu Opini dan Pelaporan Atas Laporan Keuangan. Jakarta: IAPI.

Institut Akuntan Publik Indonesia (IAPI). 2013. Standar Audit (SA) Seksi 705: Modifikasi Terhadap Opini Dalam Laporan Auditor Independen. Jakarta: IAPI.

Institut Akuntan Publik Indonesia (IAPI). 2013. Standar Audit (SA) Seksi 330: Respons Auditor Terhadap Risiko yang Telah Dinilai. Jakarta: IAPI.

Institut Akuntan Publik Indonesia (IAPI). 2013. Standar Audit (SA) Seksi 570: Kelangsungan Usaha. Jakarta: IAPI.

Jayanti, Queenaria dan Rustiana. 2015. "Analisis Tingkat Akurasi Model Prediksi Kebangkrutan Untuk Memprediksi Voluntary Auditor Switching". MODUS Vol. 27 No.2.

Kim, Hakwoon., Hyoik Lee \& Jong Eun Lee. 2015. "Mandatory Audit Firm and Audit Quality". The Journal of Applied Business Research. Vol. 31 No. 3 June 2015.
Kementrian Keuangan Republik Indonesia. 2008. Peraturan Menteri Keuangan Republik Indonesia Nomor 17/PMK.01/2008 Tentang Jasa Akuntan Publik.

Kementrian Keuangan Republik Indonesia. 2015. Peraturan Menteri Keuangan (PMK) No. 20 tahun 2015 Tentang Praktik Akuntan Publik.

Lenap, Indria Puspitasari. 2015. "Analisis Model Altman Z Score dalam Memprediksi Kebangkrutan pada Perusahaan Pertambangan di Bursa Efek Indonesia". Jurnal Aksioma Vol. 14 No.1 Juni 2015.

Lie, Christian., Puruwita Wardani \& Toto Warsoko Pikir. 2016. "Pengaruh Likuiditas, Solvabilitas, Profitabilitas, dan Rencana Manajemen terhadap Opini Audit Going Concern". Berkala Akuntansi dan Keuangan Indonesia. Vol.1 No.2 (84-105).

Nanda, Fini Rizki. 2015. "Pengaruh Audit Tenure, Disclosure, Ukuran KAP, Debt

Default, Opinion Shopping dan Kondisi Keungan terhadap Penerimaan Opini Going Concern. Jurnal Ekonomi, Manajemen dan Akuntansi. Vol.24 No.1 Juni 2015 
Natalia, Desi Br Sinurat dan Eddy Rismanda Sembiring. 2016. "Pengaruh Profitabilitas, Leverage, Struktur Kepemilikan dan Status Perusahaan Terhadap Pengungkapan Laporan Keuangan Pada Perusahaan Manufaktur yang terdaftar di Bursa Efek Indonesia". JRAK Vol. 2 No.1.

Nurdin, Emilia dan Selfy Dewita Yusran. 2017. "Pengaruh Opini Audit dan Reputasi Auditor Terhadap Voluntary Auditor Switching". Jurnal Akuntansi dan Keuangan Volume II No.2 Oktober 2017.

Pranata, Nika. (28 Desember 2015). Artikel Kutukan Negara Kaya Sumber Daya Alam. Lipi.go.id. Diakses 16 Februari 2018, dari http://lipi.go.id/lipimedia/kutuk an-negara-kaya-sumber-dayaalam/10382

PricewaterhouseCoopers (PwC). 2015. Mining Report 2015.

Sadirin, Ahmad dan I Putu Gede Diatmika. 2017. "Pengaruh Financial Distress, Perkara Pengadilan, dan Kepemilikan Manajerial Terhadap Penerimaan Opini Audit Going Concern." E-Journal Universitas Pendidikan Ganesha Vol. 8.2

Sekaran, U., \& Bougie, R. (2016). Research Methods for Business. Italia: Wiley.
Setiadamayanthi, Ni Luh Ayu dan Md. Gd. Wirakusuma. 2016. "Pengaruh Auditor Switching dan Financial Distress Pada Opini Audit Going concern". E-Jurnal Akuntansi Universitas Udayana Vol. 15.3 Juni 2016.

Setiawan, Feri dan Bambang Suryono. 2015. "Pengaruh Pertumbuhan Perusahaan, Profitabilitas, Likuiditas dan Leverage Terhadap Opini Audit Going Concern". Jurnal Ilmu \& Riset Akuntansi Vol. 4.3

Soepriyanto, Gatot dan Arien Djunaidi. 2013. "Pengaruh Pergantian Auditor dan Kualitas Audit Terhadap Opini Audit Going concern". Binus Business Review Vol. 4 No.1 Mei 2013.

Subramanyam, K. R, 2014. Financial Statement Analysis. United State of America: McGraw Hill.

Tuanakotta, Theodorus M. 2013. Audit Berbasis ISA (International Standards on Auditing). Jakarta: Salemba Empat.

Undang-Undang Republik Indonesia No. 4 Tahun 2009 Tentang Pertambangan Mineral dan Batubara. 
Utami, Sinar Putri. (19 November 2017). PKP2B Asmin Koalindo berakhir, kreditur gigit jari. Kontan.co.id. Diakses 3 Agustus 2018, dari https://nasional.kontan.co.id/ne ws/pkp2b-asmin-koalindoberakhir kreditur-gigit-jari

Verdiana, Komang Anggita dan I Made Karya Utama. 2013. "Pengaruh Reputasi Auditor, Disclosure, Audit Client Tenure, Pada Kemungkinan Pengungkapan Opini Audit Going concern". E-Journal Akuntansi Universitas Udayana Vol.5 (530-543).

Weygandt, J. J., \& dkk. (2015). Financial Accounting: IFRS Edition. United States of America: John Wiley \& Sons, Inc.

Wibisono, Edward Akiko. 2013. "Prediksi Kebangkrutan, Leverage, Audit Sebelumnya, Ukuran Perusahaan, Terhadap Opini Going concern Perusahaan Manufaktur BEI". Jurnal EMBA, Vol. 1 (362373).
Wulandari, Soliyah. 2014. "Analisis Faktor-faktor yang Mempengaruhi Auditor dalam Memberikan Opini Audit Going Concern". E-Jurnal Akuntansi Universitas Udayana Vol.6 No.3.

Yaqin, Muhammad Ainun \& Maria M. Ratna Sari. 2015. "Pengaruh Faktor Keuangan dan Non Keuangan pada Opini Audit Going Concern". EJurnal Akuntansi Universitas Udayana. Vol.11 No.2.

www.bkpm.go.id

www.idx.co.id

www.idx.co.id

www.kemenperin.go.id 